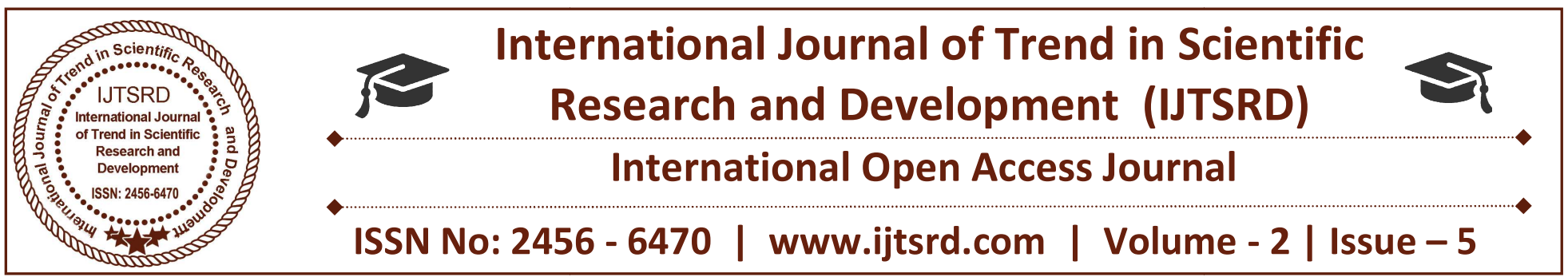

\title{
Critical Appraisal of Presidential Rule Imposed on State
}

\author{
Kshitij Guatam \\ B.B.A., LL.B. (HONS.) - II SEM., Indore Institute of Law, Affiliated To DAVV and BCI, \\ Indore, Madhya Pradesh, India
}

\section{ABSTRACT}

India or Indian governmental issues same words for whom who don't know about the political arrangement of our nation, who are not cognizant how political gathering controlled our constitution only for individual advantage, however not for good administration. Presently the inquiry emerge that Indian constitution is a inflexible constitution or not, a constitution which was effortlessly corrected or not a constitution which work as indicated by a political gathering or not there are such a large number of question emerge but rather still our political pioneer are not prepared to acknowledge their misstep. This is something incorrect why our constitution gives such power to the association government to outright control over the state and on the off chance that it gives so then why we take after the rule of federalism. From the earliest starting point article 356 is recharged for its miss utilize and move toward becoming the dynamic apparatus for focal government to control over the state with no reason. The dad of our constitution Dr B. R Ambedkar are absolutely ignorant that article 356 is twisted seriously by the focal government, yet as per them article 356 was one of the instrument through which focal government secure the state administration of any outer or inward hostility. There is dependably a major question whether India take after the rule of federalism or not. The word association does not demonstrate any kind of league, since it is utilized additionally in the introduction of the constitution of the unified express the model of organization; in the prelude of the British north America (which as indicated by master Haldane, did not made a genuine league by any stretch of the imagination) still the word government was likewise said in our preface however I don't think so that in such manner we take after our preface in light of article 356 which turn into the real obstacle.

\section{History and Background}

This Act first introduced the concept of 'Division of Powers' in British India. It was an experiment where the British Government entrusted limited powers to the Provinces. But since there was very little faith lost between the British and the Indian people, the British took precautions to keep a sufficient check on the powers given to the Provinces. These precautions were manifested in the form of emergency powers under Sections 93 and 45 of this Act, where the Governor General and the Governor, under extraordinary circumstances, exercised near absolute control over the Provinces. When it was suggested in the Drafting Committee to confer similar powers of emergency as had been held by the Governor-General under the Government of India Act, 1935, upon the President, many members of that eminent committee vociferously opposed that idea. ${ }^{1}$

According to the Dr. B. R. Ambedkar Article 356 is 'Dead letter of the Indian Constitution'. In his view in future every ruling party manipulate the usage of this article in their profit and drop off the ruling party in the state to come to power in that particular state.

According to him this article never be called into the states and the President, who is endowed with these power should take proper precaution before uspending the government or administration of the provinces.

\footnotetext{
${ }^{1}$ Prasidh Raj Singh, Article 356 and Judicial Review,SSRN, ( $7^{\text {th }}$ july and 12:30 P.M.), https://poseidon01.ssrn.com/
} 
But indeed the Dr. Ambedkar' assurance presidential rule was imposed by very first President of India in 1951. And at 2 tenure of the first prime minister of India Pandit Jahawarlal Nehru imposed presidential's rule in the state by $8^{\text {th }}$ times. So the word of Dr. Ambedkar were correct on presidential rule i.e. it is a dead letter for the Indian Constitution.

After that Presidential rule was imposed 124 times till date. The first state to suffer the presidential rule was Punjab in! 951. And the last states so far who suffer the Presidential rule is Arunanchal Pradesh.

In Indira Ghandhi's tenure the Presidential rule was imposed many times i.e. 50 times In her 10 years tenure (1966-1977) presidential rule was impose 35 times and in October 1980 she again come into the power for 5 years and at that time presidential's rule was imposed 15 times.

The state who suffers the Presidential rule most of the time is Uttar Pradesh i.e. $10^{\text {th }}$ times and In Punjab it was imposed for the largest period of time i.e. more than 3000 days. Punjab was under President's rule for 5 continuous years from 1987 to 1992 .

In India the prsidential's rule was imposed on the state by 115 times and Congress or a Congress led alliance was in power at the center 84 times. This is more than $73 \%$ of the times when President's rule was imposed in the country. And the other part includes Janta alliance and Bjp alliance and the national front alliance have the remaining one i.e. 31 .

In the initial years, there were not many instances of its use. But, with passing of years, these provisions have been invoked with increasing frequency. This is evident from the data given below: Period Frequency 1950-1954- 3

$1955-1959-3$

1960-1964-2

1965-1969 -9 (7 cases in 1967-69)

1970-1974-19

1975-1979 -21 (9 cases in 1977) 1980-1987 18 (9 cases in 1980) ${ }^{2}$

\section{Why It is Imposed on the State}

There is various ways or reason to impose the presidential's rule in the state that are:

1. State legislature is unable to elect a leader as CM.

\footnotetext{
${ }^{2}$ The Sarkaria Commission Report,

http://interstatecouncil.nic.in/SARCOMM.htm
}

2. Breakdown of a coilation.

3 . Loss of the majority in the assembly.

4. Election Imposed for unavoidable reasons.

If approved by both houses, President's Rule can continue for 6 months. It can be extended for a maximum of 3 years with the approval of the Parliament done every 6 months. If the Lok Sabha is dissolved during this time, the rule is valid for 30 days from the first sitting of the Lok Sabha provided that this continuance has already been approved by Rajya Sabha. ${ }^{3}$

Generally, president rule is applicable when there is the breakdown of a coilation which means when two or more party come together to come to power in a state and after that due to some unavoidable situation or crisis there were a dispute amongst them and the government breakdown then president rule come into the picture.

But there are some case in mid $70_{\mathrm{s}}$ and $80_{\mathrm{s}}$ when inspite of having majority in the assembly there were a breakdown in the government because of the dispute arising with the ruling party of the center. There are also some instances when due to the chief minister of that particular state has tendered his resignation for various reasons like disqualification by courts e.t.c.

The 44th Amendment Act of 1978 introduced a new provision to put a restraint on the power of the Parliament to extend President's rule in a state. According to this provision, President's rule can only be extended over a year every 6 months under following conditions:

There is already a National emergency throughout India, or in the whole or any part of the state.

The commission of election certifies that elections cannot be conducted in the concerned state.

President's rule can be revoked at any time by the President and does not need the Parliament's approval.

Until the mid-1990s, President's rule was often imposed in states through abusing the authority of Governors who were in collusion with the central

\footnotetext{
${ }^{3}$ K. Jayasudha Reddy and Joy V. Joseph, EXECUTIVE DISCRETION AND ARTICLE 356 OF THE CONSTITUTION OF INDIA: A Comparative Critique,EJCL, $\left(10^{\text {th }}\right.$ july $\left.7: 00 P . M.\right)$
} 
government. The Supreme Court of India in March 1994 instituted a rule by which such abuse has been drastically reduced.

The President acquires the following powers when the President's Rule is imposed in a state -

1. He can take up the functions of the state government and powers vested in the governor or any other executive authority in the state.

2. He can declare that the powers of the state legislature are to be exercised by the Parliament.

3. He can take all other necessary steps including the suspension of the constitutional provisions relating to anybody or authority in the state.

The President dismisses the state council of ministers headed by the chief minister.

The state governor, on behalf of the President, carries on the state administration with the help of the chief secretary of the state or the advisors appointed by the President. This is the reason why a proclamation under Article 356 is popularly known as the imposition of 'President's Rule' in a state. Further, the President either suspends or dissolves the state legislative assembly. In case of dissolution fresh elections are held for the state assembly.

The Parliament passes the state legislative bills and the state budget.

When the state legislature is thus suspended or dissolved -

1. The Parliament can delegate the power to make laws for the state to the President or to any other authority specified by him in this regard.

2. The Parliament or in case of delegation, the President or any other specified authority can make laws conferring powers and imposing duties on the Centre or its officers and authorities, the President can authorize, when the Lok Sabha is not in session, expenditure from the state consolidated fund pending its sanction by the Parliament.

3. The President can promulgate, when the Parliament is not in session, ordinances for the governance of the state. A law made by the Parliament or president or any other specified authority continues to be operative even after the President's Rule. This means that the period for which such a law remains in force is not co- terminus with the duration of the proclamation. But it can be repealed or altered or re-enacted by the state legislature.

It should be noted here that the President cannot assume to himself the powers vested in the concerned state high court or suspend the provisions of the Constitution relating to it. In other words, the constitutional position, status, powers and functions of the concerned state high court remain same even during the President's Rule. ${ }^{4}$

\section{Criticism}

The present situation in India shows that the 'deadletter' provision - as Dr. Ambedkar hoped it would be has become a frequently invoked, not-so-dead Article; it has been activated more than a hundred times till today. The National Commission to Review the Working of the Constitution (NCRWC), which was established on February 22, 2000, on the basis of a joint resolution of the Government of India, Ministry of Law, Justice and Company Affairs (Department of Legal Affairs), submitted its extensive report in March 2002.

In its analysis, the NCRWC stated that in at least twenty out of the more than one hundred instances, the invocation of Article 356 might be termed as a misuse.

It is difficult to believe that, during his tenure as the Governor of the State of Uttar Pradesh, Romesh Bhandari made any real effort to install a popularly elected government or to conduct a constitutionally mandated floor-test to test the strength of the Legislative Assembly in the State for identifying a majority party before prompting the application of the Article by the President. After the fall of the Mayawati Government in the State of Uttar Pradesh, it might have been justifiable to impose President's Rule. But it was also necessary to hold fresh elections as soon as possible. The mala fides of the Union Executive in preventing the assumption of office by an unfavourable political entity became clearly manifest in Governor Bhandari's actions and the decision of the United Front Government at the Center, to re-impose President's Rule in Uttar Pradesh. The worst damage may possibly have been

$412^{\text {th }}$ july ,5:00 P.M.

https://www.careerride.com/mchoice/what-are-effects-ofpresidents-rule-27849.aspx 
done through the office of the Governor, because the Governor cannot be held responsible for his or her actions. H. M. Seervai pointed out that the Governor can be removed only by the President and that the President acts on the advice of the Council of Ministers; hence the Governor is in office pretty much at the pleasure of the Union Executive. This may act as a bias whenever the Governor's duty requires him to go against the desires of the Union Executive. ${ }^{5}$

In its report, the NCRWC recommended that the President should appoint or remove the Governor in consultation with the Chief Minister of the State. This may act as a restraint on the misuse of power by the Office of the Governor.

Another example of misuse of Article 356 was the imposition of President's Rule in the State of Gujarat from September1996 to October 1996, following the incidents of violence indulged in by members of the Gujarat Legislative Assembly. Soli Sorabjee pointed out that violence within the Assembly cannot be treated as an instance of failure of the constitutional machinery; it would otherwise become very easy for malicious legislators to dissolve a duly elected legislative body by creating pandemonium in the Assembly and thereby prompting improper invocation of Article 356. The correct procedure to be followed in such a situation is to pass suitable legislation for disqualifying the guilty legislators. majority party before prompting the application of the Article by the President.

Arunachal Pradesh, a distant state in the Indian NorthEast, is under President's Rule. It was imposed on January 26, 2016. It has invited acrimony and accusations from all sides, and the dismissed government has asked the Supreme Court to referee it. The details are murky. The center and the state are run by opposing political parties. The National Democratic Alliance rules India; the Congress-led United Progressive Alliance ruled the state. The governor, an appointee of the central government, recommended President's Rule because a mandatory provision of the Constitution wasn't followed. Legislative assemblies must convene once every six months: so says the Constitution. The Arunachal assembly didn't. With state government not functioning in accordance with the provisions of the Constitution, it was dismissed.
The Congress party though saw things differently. It was in power in the state. But a faction broke away and joined hands with the opposition. The Assembly was scheduled to meet in early January of 2016. The government had plans to prove its majority in the floor of the Assembly then.

The governor though, acting on his own, brought forward the date of the Assembly. He scheduled it for mid-December of 2015. The ministry now had less time to "arrange" its majority. It ordered a lockdown of the Assembly; no sessions could be held.

But the breakaway faction along with the opposition convened a "session" outside the Assembly premises: it was a theatre of the absurd.

Political defections are common in India, but the rules that govern their validity are complex. The speaker decides if such defections are legal. The breakaway faction voted out the incumbent speaker, and elected one of its members as the new speaker. They had effectively validated their defection. But the Assembly was still under lockdown. Eventually, time ran out. Six months had elapsed since the last session. And the governor found in that the perfect excuse to recommend dismissal of the government.

The Arunachal facts demonstrate the deadly effects of Article 356. It is an invitation to chaos, to create one where none exists. It is particular enticing when different parties hold power at the center and the states. The center holds all the constitutional cards. It can create uncertainty, dismiss a government, and install a new one or invite fresh polls. Parties of all hues have enacted this script. None of this should be surprising: The provision was made to order for abuse. 6

President's Rule has been imposed more than 125 times. That's an average of two proclamations every year. Not all of these were abusive; some were necessary. The State of Jammu and Kashmir in northern India is currently under President's Rule, and without controversy. The people elected a fractured State Assembly. No party or coalition has a working majority, and none were willing to develop one. The president had little choice but to invoke Article 356. Parties have time to parley among themselves. If no solution is found, eventually a new mandate will be sought. 


\section{Judicial Trend}

The susceptibility of a Proclamation under Article 356 to judicial review is beyond dispute, because the power under Article 356(1) is a conditional power. In the exercise of the power of judicial review, the court is entitled to examine whether the condition has been satisfied or not. So the controversy actually revolves around the scope and reach of judicial review. From the decisions in the case of State of Rajasthan $\mathbf{v}$. Union of India and the Bommai case, it is clear that there cannot be a uniform rule applicable to all cases.

It is bound to vary depending upon the subject matter, nature of the right, and other factors. However, where it is possible the existence of satisfaction can always be challenged on the ground that it is 'mala fides or based on wholly extraneous and irrelevant grounds.'

The relevance of judicial review in matters involving Article 356 is also emphasized in the Supreme Court judgment in State of Madhya Pradesh v. Bharat Singh, where the Supreme Court held that it was not precluded from striking down a law passed prior to a Proclamation of Emergency, as ultravires to the Constitution, just because the Proclamation was in force at that time.

Judicial review of the Proclamation under Article 356(1) was first tested in State of Rajasthan $\mathbf{v}$. Union of India. The Supreme Court, being the ultimate interpreter of the Constitution, has the power of judicial review on all actions emanating from or empowered by any constitutional provision. Though the power of the President under Article 356 concerns his political judgment and the courts usually avoid entering the political thicket, this power does not enjoy blanket immunity from judicial review. It has to be determined in the individual cases on the basis of justifiability, which is distinct from judicial review. But unless the mala fides of the Presidential Proclamation is shown, the Courts have been exhorted by the Supreme Court to avoid delving into the President's satisfaction for want of judicially manageable standards. ${ }^{7}$

This point is amply evident in the case of Minerva Mills and Others v. Union of India and Others, where the Supreme Court dwelt extensively on its power to examine the validity of a Proclamation of Emergency issued by the President. The Supreme Court in this matter observed, inter alia, that it should not hesitate to perform its constitutional duty merely because it involves considering political issues. At the same time, it should restrict itself to examining whether the constitutional requirements of Article 352 have been observed in the declaration of the Proclamation and it should not go into the sufficiency of the facts and circumstances of the presidential satisfaction in the existence of a situation of emergency. Thus we can safely conclude that, though limited, the Presidential Proclamation under Article 356 is subject to judicial review.

\section{Conclusion}

As we can see that how presidential rule was abuse by many central parties in their times. That's why Dr. Ambedkar said that at the meeting of the constitutional assembly that this article is the 'Dead letter of the Indian Constitution'.

But after the landmark judgement of S. R. Bommai Vs Union Of India this instace didn't stop but slow down. Indian judiciary the frequently use of article 356 was a bridge and after S. R. Bommai case where supreme court provide the proper guidelines for the proclamation of state emergency and has power to invoke and declare it null and void if the proclamation was imposed without any cause show case the it is very necessary that the proclamation of article 356 should be used in rare of the rarest case where it require.

As indicated by me article 356 require certain amend as given beneath:

1. The legislative leader of a state ought to present their answer to the president and boss equity of high court and if both are concur that state isn't working as per the constitution at that point just president control was forced.

2. During state crisis association has no capacity to revise or make any law in matter of state list

3. The fulfilment of the president isn't the fulfilment of the focal government.

4. The condition "or something else" ought to be expelled from the article 356 in light of the fact that it offer capacity to the association government to force state crisis without representative report

5. It is fundamental that president ought not work as per the focal government, but rather he should work as per the constitution of India.

6. Before decree of state crisis the representative report and president fulfilment on the senator report ought to be distributed in every day daily paper.

\footnotetext{
${ }^{7}$ Supra2
} 